\title{
De vergeefse uitholling van allesomvattende zekerheidsrechten
}

\section{Inleiding}

Een bank heeft doorgaans een sterke zekerheidspositie in het faillissement van haar schuldenaar, doordat zij op nagenoeg alle activa van de schuldenaar pand- of hypotheekrechten heeft. Hierdoor kan een bank een aanzienlijk deel van haar vorderingen verhalen op de opbrengst van de tot zekerheid strekkende goederen. Het contrast met de overige schuldeisers is groot. Zij hebben immers veelal geen of slechts lager gerangschikte pand- of hypotheekrechten.

Verschillende auteurs bepleiten ingrijpen door de wetgever om ervoor te zorgen dat de overige schuldeisers een groter deel van hun vorderingen voldaan krijgen in faillissement. ${ }^{1}$ Een steeds terugkerende suggestie is om een schuldeiser met slechts enkele pandrechten gunstiger te behandelen dan een schuldeiser met pandrechten op nagenoeg alle goederen van de schuldenaar. In België heeft een schuldeiser met pandrechten op vorderingen geen last van een afkoelingsperiode behorende bij de Belgische surseance van betaling ('gerechtelijke reorganisatie'), mits partijen de vorderingen specifiek in de vestigingsakte hebben aangeduid. ${ }^{2}$ Indien de vestigingsakte geen specifieke aanduiding van de vordering bevat, bijvoorbeeld in het geval het pandobject de gehele onderneming (handelszaak) is, kan de schuldeiser zijn pandrechten op de vorderingen van de onderneming niet uitoefenen gedurende deze afkoelingsperiode. ${ }^{3}$ Ook het Zuid-Afrikaanse recht maakt onderscheid tussen pandrechten op basis van de aanduiding van het onderpand. In Zuid-Afrika geldt sinds 1993 het vereiste van inschrijving van pandrechten op roerende zaken in een openbaar toegankelijk pandregister. ${ }^{4}$ Registerpandrechten op specifiek aangeduide zaken hebben een hogere rang dan registerpandrechten op algemeen omschreven zaken. ${ }^{5}$

In Nederland bestaat geen onderscheid tussen pandrechten op basis van de omschrijving van het onderpand ten tijde van de vestiging. Een specifieke aanduiding van het onderpand

1 F.J.L. Kaptein, Pandrecht. Een rechtsvergelijkend onderzoek naar de gevolgen van het vuistloze en stille karakter van het pandrecht, Den Haag: Bju 2016, p. 300 e.v.; S.C.J.J. Kortmann, Het faillissement, een paradijs voor banken (afscheidsrede/Van der Grintenlezing, Radboud Universiteit), Nijmegen 2017, p. 15 e.v.

2 Art. XX.52 Wetboek van economisch recht (WER).

3 Vgl. E. Dirix \& R. Jansen, 'Wet continuïteit ondernemingen: De positie van de schuldeisers en het lot van lopende overeenkomsten', in: Faillissement en Reorganisatie 48 (11 september 2013), p. 21.

$4 \quad$ R. Brits, Real security law, Kaapstad: Juta 2016, p. 230 e.v.

$5 \quad$ Art. 1 Wet op Sekerheidstelling deur Middel van Roerende Goed 57 van 1993. 


\section{VAN HOOF}

leidt niet tot een gunstigere behandeling dan een aanduiding van bijvoorbeeld alle bestaande en toekomstige zaken. Het tijdstip van de vestiging bepaalt de rang, ongeacht of de schuldeiser een pandrecht krijgt op één goed of pandrechten op alle goederen. Ook bestaat er geen verschil in de bevoegdheden van de pandhouders. Zwalve heeft de invoering verdedigd van een uitzondering op de prioriteitsregel, die zou inhouden dat 'alle bijzondere zekerheidsrechten die in het kader van de normale bedrijfsvoering zijn gevestigd prevaleren bóven het eerder gevestigde generale zekerheidsrecht. ${ }^{16}$ Het door Zwalve gemaakte onderscheid heeft betrekking op de aanduiding van het zekerheidsobject. Zwalve ontleende deze regel aan het recht dat in het gewest Holland gold ten tijde van de Republiek der Zeven Verenigde Nederlanden. ${ }^{7}$ Zekerheidsrechten waren 'bijzonder' of 'speciaal' wanneer partijen het zekerheidsobject specifiek bij de vestiging hadden aangeduid. ${ }^{8}$ Zekerheidsrechten waren 'algemeen' of 'generaal' wanneer partijen het zekerheidsobject in algemene bewoordingen hadden aangeduid. ${ }^{9}$ De aanduiding was weliswaar algemeen, maar het rechtsgevolg was dat er evenveel zekerheidsrechten tot stand kwamen als er goederen aan de schuldenaar toebehoorden. Het was dus niet één zekerheidsrecht op meer goederen. ${ }^{10}$ De door Zwalve bepleite invoering van de regel houdt dus in dat een pandrecht met een specifiek aangeduid zekerheidsobject een hogere rang krijgt dan eerder gevestigde pandrechten met algemene, veelal allesomvattende, aangeduide zekerheidsobjecten.

In deze bijdrage zet ik uiteen waarom de wetgever geen onderscheid moet maken tussen pandrechten op basis van de aanduiding van het pandobject bij de vestiging. De door Zwalve verdedigde uitzondering op de prioriteitsregel kwam inderdaad voor in de Republiek der Verenigde Nederlanden ( $\$ 3$ en 4 ) en later in Zuid-Afrika ( $\$ 6)$, maar zij was niet het onverdeelde succes waarvan Zwalve uitgaat. De schuldeiser die behoefte had aan veel onderpand, zag er op toe dat zijn schuldenaar net zoveel goederen specifiek aanduidde als de schuldeiser verlangde. Ook zonder een algemene aanduiding van het onderpand kon een schuldeiser hierdoor langs een omweg op nagenoeg alle goederen zekerheid krijgen. Dit praktische bezwaar is een van de argumenten geweest om de regel niet in het BW van 1838 op te nemen (§5). Verder bestaan er nog enkele bezwaren tegen de invoering van de uitzondering op de prioriteitsregel in het hedendaagse recht $(\$ 7)$.

Meer in algemene zin dreigt bij een gunstigere behandeling van speciale zekerheid in verhouding tot generale zekerheid een vlucht naar speciale zekerheid. Zowel de Nederlandse als de Zuid-Afrikaanse wetgever lijkt deze les uit het verleden niet te hebben getrokken. Zo heeft de Nederlandse wetgever in 1992 tevergeefs een drempel opgeworpen voor het

W.J. Zwalve, 'Too convenient a form of security to be lightly abolished', WPNR 6665 (2006), p. 358. Vgl. W.J. Zwalve, 'Over generale en bijzondere zekerheidsrechten, Tekst en Uitleg VIII', AA 55 (2006)1, p. 23. Ibidem.

8 Zie: V.J.M. van Hoof, Generale zekerheidsrechten in rechtshistorisch perspectief (Serie Onderneming en Recht, deel 86), Deventer: Wolters Kluwer 2015, §4.4.1.

9 Ibidem.

10 Van Hoof 2015, §4.6.1. 


\section{DE VERGEEFSE UITHOLLING VAN ALLESOMVATTENDE ZEKERHEIDSRECHTEN}

verschaffen van zekerheid op alle bestaande en toekomstige vorderingen van een pandgever (§8). Het sinds 1993 bestaande onderscheid tussen generale en speciale registerpandrechten in Zuid-Afrika (§9) lijkt vooralsnog niet tot een vlucht naar speciale zekerheid te hebben geleid, maar ik vermoed dat dit slechts een kwestie van tijd is (\$10). Ik vang aan met de hoofdregel die de rang tussen verschillende pandrechten beheerst, het Romeinsrechtelijke adagium prior tempore potior iure.

\section{Prior tempore potior iure}

In het Romeinse recht had een schuldeiser met een ouder pand- of hypotheekrecht voorrang boven een schuldeiser met een jonger pand- of hypotheekrecht. ${ }^{11}$ Deze rangorde vloeide voort uit het adagium prior tempore, potior iure, oftewel eerder in tijd, sterker in recht. Het Romeinse recht kende ook zogenaamde speciale en generale pand- en hypotheekrechten. ${ }^{12}$ Het onderscheid was net als in het Rooms-Hollandse recht gelegen in de aanduiding van het onderpand. Een specifieke aanduiding van het pandobject leidde tot de vestiging van een speciaal pandrecht. Een algemene aanduiding leidde tot de vestiging van een generaal pandrecht. De partijbedoeling was doorslaggevend bij de beantwoording van de vraag of het om een generaal of speciaal pandrecht ging. Keizer Justinianus bepaalde in 528 dat een rechter de partijbedoeling in het oog moest houden bij de uitleg van een pandakte:

Indien iemand in de akte van om het even welk contract de woorden heeft opgenomen 'onder waarborg en voor risico van de mij toebehorende goederen' of 'ik sta toe dat u voldaan wordt door opvordering van deze goederen', volstaan deze woorden voor een hypotheekrecht op zowel de huidige als de toekomstige zaken die de debiteur heeft; zij worden niet meer op grond van vroegere verordeningen geacht de vermelding van een speciale hypotheek in te houden, omdat het juist is veeleer naar de wil van de contractanten dan naar de redactie van de bewoordingen te kijken. ${ }^{13}$

11 C. 8,17(18),1 (Imp. Severus en Caracalla in 197); C. 8,17(18),7 (Imp. Diocletianus en Maximianus in 293). Vgl. M. Kaser, Das römische Privatrecht I: das altrömische, das vorklassische und klassische Recht, 2e druk, München 1971, §110, III.

12 Zie over het onderscheid tussen speciale en generale pandrechten in het Romeinse recht: H. Wagner, Voraussetzungen, Vorstufen und Anfänge der römischen Generalverpfändung, Marburg: Elwert 1968, p. 68 e.v.; Van Hoof 2015, §2.3.1.

13 C. 8,16(17),9,pr (Imp. Justinianus) Si quis in cuiuscumque contractus instrumento ea verba posuerit: 'fide et periculo rerum ad me pertinentium' vel 'per earum exactionem satisfieri tibi permitto', sufficere ea verba ad rerum tam earum quas in praesenti debitor habet quam futurarum hypothecam, nec ex prioribus sanctionibus minus habere speciali hypothecae memoria videri, cum sit iustum voluntates contrahentium magis quam verborum conceptionem inspicere. De vertaling ontleende ik aan J.E. Spruit e.a., Corpus Iuris Civilis VIII, Tekst en vertaling, Amsterdam: KNAW 2007. 


\section{VAN HOOF}

Voor de toepassing van de prioriteitsregel maakte het Romeinse recht geen onderscheid tussen speciale en generale zekerheidsrechten. ${ }^{14}$ Zo bepaalden de keizers Severus en Caracalla in 194 dat een ouder pandrecht op alle goederen van een schuldenaar voorrang had boven een later gevestigd vuistpandrecht op een enkele zaak van de schuldenaar:

\footnotetext{
Ook al komt vast te staan dat uw tegenpartij op bepaalde zaken een speciaal pandrecht en op het gehele vermogen een generale hypotheek heeft verkregen en dat hij ten aanzien van alle goederen hetzelfde recht heeft, moet toch met oog voor de omstandigheden recht worden gedaan. (1) Indien het derhalve zeker is dat hij op de goederen die hem afzonderlijk als pand zijn verbonden, zijn gehele schuld kan verhalen, zal de gouverneur bevelen dat de goederen van hetzelfde vermogen, die u later in pand hebt gekregen, in de tussentijd niet worden weggehaald. ${ }^{15}$
}

In deze casus had de oudste schuldeiser goederen specifiek aan zich laten verpanden en voorts de overige goederen van de schuldenaar generaal. Deze combinatie van een speciaal zekerheidsrecht naast een generaal zekerheidsrecht kwam volgens Gaius vaak voor. ${ }^{16}$ Het onderscheid tussen speciale en generale pandrechten maakte weliswaar voor de prioriteitsregel niet uit, maar voor andere rechtsgevolgen wel. ${ }^{17}$ In de bovenstaande tekst ging de schuldeiser over tot uitwinning van zijn zekerheidsrechten op generaal verpande zaken die zich bevonden bij een andere schuldeiser met een jonger vuistpandrecht. Volgens keizers Severus en Caracalla kon de vuistpandhouder de actio Serviana van de oudste schuldeiser afweren totdat de oudste schuldeiser de speciaal aan hem verpande zaken had uitgewonnen. Dit verweer staat ook wel bekend als het beneficium excussionis realis (het zakelijk voorrecht van (eerdere) uitwinning). ${ }^{18}$

Indien een toekomstig goed meermaals bij voorbaat was bezwaard en daarna in het vermogen van de schuldenaar kwam, kreeg de schuldeiser aan wie de schuldenaar de zaak als eerste bij voorbaat had bezwaard de hoogste rang. De rang werd dus niet bepaald door het tijdstip van het ontstaan van het pandrecht, maar het tijdstip van de voltooing van de

14 C. 8,17(18),6 (Imp. Valerianus en Galienus in 260). Voor andere rechtsgevolgen, zoals zaaksgevolg, was het onderscheid wel van belang. Vgl. Van Hoof 2015, §2.3.

15 C. 8,13(14),2 (Imp. Severus en Caracalla in 194) Quamvis constet specialiter quaedam et universa bona genera liter adversarium tuum pignori accepisse et aequale ius in omnibus habere, iurisdictio ta-men temperanda est. (1) Ideoque si certum est posse eum ex his, quae nominatim ei pignori obligata sunt, universum redigere debitum, ea, quae postea ex isdem bonis pignori accepisti, interim non auferri praeses iubebit.

16 D. 20,1,15,1 (Gaius formula hypothecaria).

17 Zie: Van Hoof 2015, §2.3.

18 De benaming beneficium excussionis realis stamt uit de Middeleeuwen. Vgl. Wagner 1968, p. 85-6; E. Koops, Vormen van subsidiariteit (diss. Leiden), 's-Gravenhage: Boom 2010, p. 49; W.J. Zwalve, 'Tekst en uitleg XII', GROM XXVII (2010), p. 135. 


\section{DE VERGEEFSE UITHOLLING VAN ALLESOMVATTENDE ZEKERHEIDSRECHTEN}

vestiging(shandeling) bij voorbaat. ${ }^{19}$ Paulus beschreef deze uitkomst als volgt:

Als een niet-eigenaar dezelfde zaak op verschillende tijdstippen aan twee schuldeisers heeft verpand, is de positie van de eerste schuldeiser het sterkst, hoewel als wij een zaak van verscheidene nieteigenaars in pand krijgen, de bezitter de sterkste positie heeft. ${ }^{20}$

Ulpianus leek echter de opvatting te verdedigen dat schuldeisers met op verschillende tijdstippen gevestigde pandrechten een gelijke rang hadden ten aanzien van goederen die na de vestigingen (bij voorbaat) door de schuldenaar waren verkregen:

Stel dat ik jegens u alles wat ik zal verkrijgen als pand verbonden heb alsmede jegens Titius afzonderlijk een perceel grond voor het geval dat ik hiervan eigenaar zal worden. Indien ik dan later de eigendom ervan verkrijg, hebben, naar Marcellus meent, beide schuldeisers ten aanzien van het pand een concurrente positie (...). ${ }^{21}$

Verschillende auteurs nemen hier aan dat de pandrechten van beide schuldeisers tegelijkertijd bij voorbaat zijn gevestigd en de schuldeisers om die reden dezelfde rang hebben. ${ }^{22}$ Van een uitzondering op de prioriteitsregel is dan geen sprake.

Schuldeisers die de aankoop van een zaak mogelijk maakten kregen een hoger gerangschikt zekerheidsrecht op de verworven zaak dan schuldeisers die eerder de zaak aan zich bij voorbaat hadden laten verpanden. ${ }^{23}$ De verklaring voor de hoge rang van de aankoopfinancier lijkt te zijn geweest dat die oudere schuldeiser helemaal geen verhaalsobject had gehad als de aankoopfinancier er niet was geweest. De schuldenaar had de zaak dan niet kunnen kopen. Niet alleen aankoopfinanciers profiteerden van een hogere rang. Ook schuldeisers met een later gevestigd pandrecht die kosten maakten tot instandhouding van het zekerheidsobject, gingen voor op een schuldeiser met een eerder gevestigd pandrecht. Ulpianus noemde als voorbeeld de schuldeiser die de kosten heeft gedragen om een schip te laten herstellen. ${ }^{24}$ Deze uitzonderingen op de prioriteitsregel worden in latere literatuur ook wel

19 Vgl. H. Dernburg, Das Pfandrecht nach den Grundsätzen des heutigen römischen Rechts, Leipzig: Hirzel 1860, p. 246-247; J.E. Jansen, 'Potharst/Serrée in het Romeinse recht. Enige opmerkingen over het overdragen van een goed onder voorbehoud van een beperkt recht', GROM XXV (2008), p. 82.

20 D. 20,4,14 (Paulus 14 ad Plautius) Si non dominus duobus eandem rem diversis temporibus pigneraverit, prior potior est, quamvis, si a diversis non dominis pignus accipiamus, possessor melior sit.

21 D. 20,4,7,1 (Ulpianus 3 disputationum) Si tibi quae habiturus sum obligaverim et Titio specialiter fundum, si in dominium meum pervenerit, mox dominium eius adquisiero, putat Marcellus concurrere utrumque creditorem et in pignore (...).

22 Onder vele anderen: Dernburg 1860, p. 259; P. Frezza, Le garanzie delle obbligazioni. Corso di diritto romano, Garanzie reali, Padova: Cedam 1963, p. 257; G.H. Potjeqijd, Beschikkingsbevoegdheid, bekrachtiging en convalescentie, Deventer: Kluwer 1998, p. 302; Koops 2010, p. 37, noot 217.

23 D. 20,4,7,pr (Ulpianus 3 disputationum); C. 8,17(18),7 (Imp. Diocletianus en Maximianus in 293) en Nov. 97,3. Vgl. Jansen 2008, p. 85 e.v.

24 D. 20,4,5 (Ulpianus 3 disputationum). 


\section{VAN HOOF}

privilegia vanwege in rem versio genoemd, omdat de gesecureerde geldsommen ten goede kwamen aan de zaak. ${ }^{25}$ De Romeinen gingen echter niet zo ver, een latere schuldeiser een hogere rang toe te kennen zonder dat daarvoor een bijzondere rechtvaardiging bestond.

\section{Bijzonder gaat voor algemeen}

De prioriteitsregel gold ook in verschillende vroegmoderne Europese steden. Voor de toepassing van de regel maakte het niet uit of een zekerheidsrecht speciaal of generaal van aard was. ${ }^{26}$ Tot in het begin van de $19^{\mathrm{e}}$ eeuw kwamen in 'Nederland' generale en speciale zekerheidsrechten naast elkaar voor. Een schuldenaar kon al zijn bestaande en toekomstige goederen (bij voorbaat) met nagenoeg één pennenstreek bezwaren met een generale hypotheek. Partijen duidden het zekerheidsobject bijvoorbeeld aan met de woorden 'alle zijn goederen roerende en onroerende Actien en Crediten tegenwoordige en toekomende geen dien uitgezondert'. ${ }^{27}$ Dit zekerheidsrecht kwam onder verschillende namen voor, zoals het generale pandrecht, de algemene onderzetting of het algemeen verband. Het hypotheekrecht omvatte, anders dan tegenwoordig, ook niet-registergoederen, zoals roerende zaken en vorderingen. Geregeld combineerden partijen een generale hypotheek met een speciale hypotheek. De hypotheekakte vermeldde dan een hypotheek op een specifiek aangeduide onroerende zaak en een hypotheek op alle overige goederen van de schuldenaar. ${ }^{28}$

In 1580 hebben de Staten van Holland bepaald dat later gevestigde speciale hypotheekrechten een hogere rang kregen dan eerder gevestigde generale hypotheekrechten:

Ende belangende constitutie ende verbande van generale hypoteque die nae twee maenden nae de publicatie van desen ghedaen sullen worden: deselve en sullen geensins hinderlick wesen ofte prejudiceren dengenen die constitutie ofte verbandt van speciael hypoteque naermaels sullen vercrijgen, sulckx dat degheene, die specialijck eenige onroerende goederen verbonden sullen worden, in deselve speciale hypoteque ende de penningen daervan procederende, sullen worden geprefereert dengenen, die ouder generale hypoteque, nae de voorsz. twee maenden nae de publicatie van desen, ghestelt sal wesen. ${ }^{29}$

Zie: H. Dernburg, Das Pfandrecht nach den Grundsätzen des heutigen römischen Rechts, Leipzig: Hirzel 1864, p. 427.

26 Zo bijvoorbeeld Leiden: Leidse Keurboek 1545,IV,XL (Van preferentie), in: H.G. Hamaker, De middeneeuwsche keurboeken van de stad Leiden; Leiden: Van Doesburgh 1873, p. 426; Amsterdam: Plac. 8-51594, in: C. Cau, Groot placaet-boeck (...), 's-Gravenhage: Van Wouw 1664, deel II, p. 2211 e.v.

27 I. Naeranus, Consultatien, advisen en advertissementen, gegeven en geschreven bi verscheiden treffelike rechtsgeleerden in Holland en elders, Rotterdam: Naeranus 1689 (V), nr. 49, p. 181 (9-5-1662).

28 J. Voet, Commentariorum ad Pandectas, Venetië: Ex Typographia Petri Valvasensis (Sumptibus Remondinianis) 1787, III, ad D. 20,1,10. p. 287; ad D. 20,1,15, p. 291.

29 Art. 35 van de Politieke Ordonnantie van de Staten van Holland van 1580. Vgl. Van Hoof 2015, §4.6.1. 


\section{DE VERGEEFSE UITHOLLING VAN ALLESOMVATTENDE ZEKERHEIDSRECHTEN}

Deze afwijking van de prioriteitsregel wordt veelal aangeduid met de regel 'bijzonder gaat voor algemeen'. ${ }^{30} \mathrm{Zij}$ gold slechts ten aanzien van de verdeling van de opbrengst van onroerende zaken. De prioriteitsregel bleef de rang tussen zekerheidsrechten op roerende zaken beheersen. ${ }^{31}$

Het voornaamste doel van de uitzondering op de prioriteitsregel was de bescherming van latere schuldeisers en de schuldenaar zelf. ${ }^{32}$ De schuldenaar die een generale hypotheek had gevestigd, behield namelijk de mogelijkheid om aan een latere schuldeiser een eersterangs hypotheekrecht te verschaffen. Hierdoor kon de hypotheekgever onder gunstigere voorwaarden krediet krijgen dan wanneer hij 'slechts' een tweederangs hypotheekrecht kon bieden. Impliciet leken de Staten van Holland uit te gaan van het idee dat de schuldeiser met een generale hypotheek meer onderpand had dan noodzakelijk was en ook na de toekenning van een hogere rang aan een latere schuldeiser ten aanzien van een specifiek goed nog voldoende zekerheid overhield.

\section{Scepsis tegen de uitzondering op de prioriteitsregel in Amsterdam en buiten Holland}

In Amsterdam leidde de invoering van de regel 'bijzonder gaat voor algemeen' tot 'verscheyden questien, processen ende misverstant. ${ }^{13}$ Volgens de Amsterdammers strekte de prioriteitsregel 'tot voordeel ende handthoudinghe aenden coophandel daer op t'welvaren der voorsz. stede principalijcken was berustende. ${ }^{134}$ De stad Amsterdam wilde de prioriteitsregel blijven toepassen en vroeg hiervoor met succes toestemming aan de Staten van Holland. ${ }^{35}$ Het Amsterdamse recht stelde de bescherming van de eerste hypotheekhouder tegen afbreuk van zijn recht centraal. Latere schuldeisers die een hypotheek lieten vestigen, kregen weliswaar een lagere rang, maar konden een openbaar register inzien om kennis te nemen van de eerder gevestigde generale hypotheek. Een generale hypotheek gaf slechts voorrang op de opbrengst van de verkoop van onroerende zaken indien de vestigingsakte was ingeschreven

30 Vgl. H. de Groot, Inleidinge tot de Hollandsche rechts-geleerdheid (met aantekeningen S.J. Fockema Andeae en L.J. van Apeldoorn), Arnhem: Gouda Quint 1939, II,48,34.

31 Vgl. Van Hoof, §4.6.2.

32 Vgl. D.G. van der Keessel, Voorlesinge oor die hedendaagse reg na aanleiding van De Groot se 'Inleiding tot de Hollandse rechtsgeleerdheyd', Amsterdam: Balkema 1964, deel III, p. 458. In mijn proefschrift noem ik enkele andere argumenten voor de uitzondering op de prioriteitsregel. Zie: Van Hoof $2015, \S 4.6 .1$.

33 Octroy van 18-3-1594 in Hantvesten privilegien willekeuren ende ordonnantien der stadt Aemstelredam, Amsterdam 1613, p. 95.

34 Ibidem.

35 Plac. 8-5-1594, in: C. Cau, Groot placaet-boeck (...), 's-Gravenhage: Van Wouw 1664, deel II, p. 2211 e.v. 


\section{VAN HOOF}

in het openbare register van de plaats waar de onroerende zaken waren gelegen. ${ }^{36}$ Latere schuldeisers konden door inzage van het register niet alleen een risicoanalyse maken, maar ook in overleg treden met de schuldeisers die reeds een generale hypotheek hadden. De inzet van dit overleg kon dan bijvoorbeeld de voorwaarden voor afstand of contractuele rangwisseling zijn.

Buiten het gewest Holland pasten sommige steden de prioriteitsregel toe, andere steden de regel 'bijzonder gaat voor algemeen'. ${ }^{37}$ De Rijselse jurist Patou schreef in 1788 dat de stedelijke wetgeving van Rijsel geen onderscheid makte tussen de werking van generale en speciale zekerheidsrechten, om te voorkomen dat een schuldenaar alle goederen afzonderlijk bezwaarde met een speciaal zekerheidsrecht: 'Si celle-ci devoit prévaloir, il dépendroit du débiteur d'éluder \& de rendre vaine \& sans effet, l'hypothèque génerale, en hypothéquant spécialement tous les biens les uns après les autres. ${ }^{138}$ Niets stond eraan in de weg dat een schuldeiser bedong dat de schuldenaar al zijn goederen afzonderlijk bezwaarde door de verschillende onroerende zaken afzonderlijk aan te duiden in de hypotheekakte. Indien de voordelen van op deze manier gevestigde 'generale' zekerheid de nadelen (zoals kosten) overstegen, hadden schuldeisers er alle belang bij allesomvattende zekerheid na te streven. Hierdoor verloor de schuldenaar alsnog de mogelijkheid om op een later moment een andere schuldeiser een hoger gerangschikt zekerheidsrecht te bieden. De uitzondering op de prioriteitsregel loste met andere woorden het gesuggereerde probleem niet op.

\section{De afschaffing van de generale hypotheek in Nederland}

De generale hypotheek en de regel 'bijzonder gaat voor algemeen' zijn in 1811 afgeschaft. ${ }^{39}$ In dat jaar kreeg de Franse Code civil uit 1804 gelding in 'Nederland' na de annexatie in het

36 Art. 37 van de Politieke Ordonnantie van de Staten van Holland van 1580. Zie over de toegankelijkheid van de registers: Van Hoof 2015, §4.4.2.2.

37 In Zutphen gold de prioriteitsregel. Rechter W. Waters schreef in 1685 dat latere schuldeisers niet werden benadeeld, omdat 'de registratie (...) op naam van de perzonen [staat], op welkers goedren de hypotheequen, hetzij door contract, hetzij door bezatinge, ofte peindinge, verkregen is; zonder dat daar een register is van de erven. Zulks, dat die geen, die yemand geld wil verschieten, of anders procederen op een byzonder erve in Over-Betuwen, d' een of d' ander toebehorende, even zo ligt by de inspectie van 't register van bezwaar kan geïnformeert worden van hyptheecquen of realisatien, staande op yemands ongerede goedren, als van die dewelke staan in specie op dit of dat erve.' Zie: Jodoci Schomakeri, Selecta consilia et responsa juris, deel V, cons. VII, nr. 33.

38 F. Patou, Commentaire sur les coutumes de la ville de Lille et de sa châtellenie, et conférences de ces coutumes avec celles voisines et le droit commun, Rijsel: Dumortier 1788, ad 8,1,5,XXXIV, p. 187.

39 Aanvankelijk doorstonden zij de omwenteling van Republiek der Verenigde Nederlanden naar Bataafse Republiek in 1795, Bataafsch Gemeenebest in 1801 en aansluitend het Koninkrijk Holland in 1806. Zie: Van Hoof 2015, §7.2.1, §7.2.2 en §7.2.3. 


\section{DE VERGEEFSE UITHOLLING VAN ALLESOMVATTENDE ZEKERHEIDSRECHTEN}

voorgaande jaar door het Franse Keizerrijk. De Code civil kende het vereiste van specialiteit; de ingeschreven hypotheekakte moest een specifieke aanduiding van de verhypothekeerde zaak bevatten. ${ }^{40}$ Het doel van dit vereiste, dat op steun van Napoleon Bonaparte kon rekenen, ${ }^{41}$ was het voorkomen dat een schuldeiser meer onderpand kreeg dan strikt noodzakelijk. ${ }^{42}$ De keuze voor specialiteit is met andere woorden de Franse manier om een overmaat aan zekerheid van de eerste hypotheekhouder te voorkomen. De regel 'bijzonder gaat voor algemeen' was daarvoor de Hollandse oplossing. Het grootste deel van Frankrijk was echter onbekend met deze uitzondering op de prioriteitsregel. Slechts enkele 'Belgische' steden in het noorden van het keizerrijk wezen de wetgever bij de totstandkoming van de Code civil op deze regel. ${ }^{43} \mathrm{Na}$ de herkregen zelfstandigheid van het (Verenigd) Koninkrijk der Nederlanden hield de Nederlandse wetgever vast aan de afschaffing van de generale hypotheek door de keuze voor het specialiteitsbeginsel.

De regel 'bijzonder gaat voor algemeen' kwam niet voor in het BW van 1838. Tammo Sijpkens $^{44}$, Tweede Kamerlid, lid van de Commissie van Redactie en rechter te Groningen, zei tijdens de behandeling van het wetsontwerp in de Tweede Kamer op 12 maart 1825:

\footnotetext{
'Want gaf de wet een voorregt aan speciale hypotheken boven de algemeene, dan werd het stelsel van algemeene hypotheken van zelf nietig, en gaf zij dit voorregt niet, dan werd het stelsel van bijzonder verband immers daarmede uitgesloten, en alle bijzondere hypotheek moest zich dan van zelf oplossen in een algemeen verband. ${ }^{45}$
}

Volgens hem leidde de regel bijzonder gaat voor algemeen tot een vlucht naar speciale zekerheid. Waarschijnlijk doelde hij op het fenomeen dat schuldeisers alle zaken afzonderlijk aan zich lieten verhypothekeren. Sijpkens constateerde bovendien dat bij gebreke van een uitzondering op de prioriteitsregel elke hypotheek generaal zou zijn. Waarom zouden partijen immers de moeite nemen om een speciale hypotheek te vestigen, als de speciale hypotheek geen voordelen kent boven een generale hypotheek?

Ik ben ervan overtuigd dat als de Fransen de generale hypotheek in Nederland niet hadden afgeschaft, zij uiteindelijk toch wel ten onder was gegaan. De regel 'bijzonder gaat voor algemeen' had haar immers tot een onvolwaardig zekerheidsrecht gemaakt. Dit leid ik onder meer af uit de ontwikkeling van de "Hollandse" generale hypotheek in Zuid-Afrika. Hol-

\footnotetext{
$40 \quad$ Vgl. Van Hoof 2015, §6.3.2.

41 P.A. Fenet, Recueil complet des travaux préparatoires du Code civil, Parijs: Videcoq 1836, XV, p. 303.

42 Zie: Van Hoof 2015, §6.4.2.2.

43 Fenet 1836, III, p. 334.

44 Over hem E.W.A. Henssen, 'Tammo Sijpkens, een Gronings 'Parketheer", in: Acht Groningse juristen en hun Genootschap (225 jaren Pro Excolendo Iure Patrio), Groningen 1986, 39-59.

45 J.C. Voorduin, Geschiedenis en beginselen der Nederlandsche wetboeken, volgens de beraadslagingen deswege gehouden bij de Tweede kamer der Staten-generaal, Utrecht: Natan 1838, IV, p. 462.
} 


\section{VAN HOOF}

landse kolonisten brachten vanaf de 17 e eeuw Rooms-Hollands recht mee naar de Kaapkolonie.

\section{De zwakke generale hypotheek in Zuid-Afrika tot 1916}

Het Zuid-Afrikaanse recht kende tot in 1916 zowel generale als speciale hypotheken. De verhouding tussen generale en speciale hypotheken werd beheerst door de regel 'bijzonder gaat voor algemeen'. ${ }^{46}$ De generale hypotheek, ook wel de general clause genoemd, ging terug op de Hollandse generale hypotheek. ${ }^{47}$

De insolventierechtelijke Ordinance 6 of 1843 (Cape Ordinance) verbond andere rechtsgevolgen aan het onderscheid tussen generale en speciale hypotheken. Een schuldeiser met een generale hypotheek moest bijdragen in de algemene faillissementskosten. Voor een schuldeiser met een speciale hypotheek gold dit niet. ${ }^{48}$ De generale hypotheek werd in faillissement gereduceerd tot het recht om zich met voorrang boven andere schuldeisers te verhalen op de resterende opbrengst (free residue) van de executie nadat daarop alle bijzondere en algemene faillissementskosten in mindering waren gebracht. ${ }^{49}$ De generale hypotheek werd vooral gebruikt als een vangnet of 'catch-all' naast andere vormen van zekerheid, bijvoorbeeld in combinatie met een speciale hypotheek. Het hooggerechtshof van Kaap de Goede Hoop stelde in 1848 het volgende vast:

(...) investigation in the office of the Registrar of Deeds proved that it was the invariable usage, custom, and practice of the Colony to insert in every bond specially hypothecating immovable property, a clause of general mortgage of all the property of the person executing the bond (...). ${ }^{50}$

In 1857 bepleitte een parlementaire commissie de afschaffing van de generale hypotheek, omdat zij de vangnetfunctie naast een speciale hypotheek ongewenst vond. De commissie constateerde in haar rapport dat het bedrag van de gesecureerde vordering doorgaans was gerelateerd aan de waarde van de speciaal verhypothekeerde zaak en de generale hypotheek

46 Re Insolvent Estate of Buissinne Van der Byl and Meyer v Sequestrator and Attorney-General 1 Menz 318.

47 Zie onder vele anderen: G.G. Visagie, Regspleging en reg aan die Kaap van 1652 tot 1806, Kaapstad: Juta 1969, p. 68 e.v. en R. Zimmermann, Das römisch-holländische Recht in Südafrika, Darmstadt: Wissenschaftliche Buchgesellschaft 1983, p. 4 e.v. Het Rooms-Hollandse recht bleef gelden toen de Engelsen de Kaapkolonie eerst in 1795 en later - na een korte vereniging van de Kaapkolonie met de Bataafse Republiek in 1802 - in 1806 bezetten.

48 Art. 8 van Ordinance 6 of 1843, in: W. Harding, The Cape of Good Hope Government Proclamations and Ordinances passed in Council, deel III, Kaapstad: Robertson 1845, p. 365. Vgl. Buchanan's decisions in insolvency, being the Cape insolvent ordinance, no. 6, 1843, Kaapstad: Juta 1906, p. 14 e.v.

49 Zie. Carelinsky and Co. and Others v Seehoff and Victor 1911 WLD 205.

50 Zie: Smith v Randall's Trustees 2 Menz 403. 


\section{DE VERGEEFSE UITHOLLING VAN ALLESOMVATTENDE ZEKERHEIDSRECHTEN}

slechts een standaardtoevoeging was. ${ }^{51}$ De generale hypotheek leidde volgens de commissie tot 'a system of grasping and over-reaching in the community'. ${ }^{52}$ De schuldeiser had immers het voordeel dat als het speciaal verhypothekeerde goed onverhoopt minder opbracht dan de gesecureerde vordering, hij zich alsnog op het vrije overschot kon verhalen. In die zin was het een voordeeltje voor de schuldeiser. De schuldenaar was niet gebaat bij de generale hypotheek.

De generale hypotheek is uiteindelijk, na de vereniging van de Zuid-Afrikaanse Republiek, de Oranje Vrijstaat, de Kaapkolonie en Natal in de Unie van Zuid-Afrika (1910), per 1 januari 1917 afgeschaft als gevolg van de invoering van de nieuwe Insolventiewet. Artikel 87 bepaalde in de eerste volzin: 'Een algemeen verband aangegaan of geregistreerd na de invoering van deze Wet verleent geen voorrecht ten aanzien van vastgoed'. ${ }^{33}$ Volgens de minister handelde hij door de afschaffing 'in the interests of the farmer when he prevented his being mortgaged over the ears. ${ }^{54}$ De minister behield de mogelijkheid om allesomvattende zekerheid te creëren op roerende zaken, gevestigd door het zogenaamde notarieel verband. Een schuldeiser met een notariële schuldbekentenis had geen goederenrechtelijk recht, maar een algemeen voorrecht in het faillissement van zijn schuldenaar. Hij moest bepaalde categoriën schuldeisers voor zich dulden, maar had voorrang boven concurrente schuldeisers op de resterende executieopbrengst (free residue). ${ }^{55}$ In theorie kan deze resterende executieopbrengst ook de executiewaarde van onroerende zaken bevatten. ${ }^{56}$ In 2015 heeft de Supreme Court of Appeal geoordeeld dat de voorrang van de schuldeiser met het generale notariële verband beperkt is tot de resterende executieopbrengst van roerende zaken. $^{57}$

\section{De nadelen van de herinvoering van de regel 'bijzonder gaat voor algemeen' in Nederland}

Allesomvattende zekerheid op roerende zaken en vorderingen is in de huidige Nederlandse praktijk aan de orde van de dag. Een pandgever kan zonder beperking al zijn bestaande en

\footnotetext{
51 Cape Law Journal (1896) XIII, p. 132.

52 Ibidem.

53 Government Gazette 1915, nr. 658. In Natal is de generale hypotheek al in 1863 afgeschaft. Zie: Art. 5 van Wet 27 van 1863. Herhaald in artikel 122 van Insolvensiewet 47 van 1887. Zie: Buchanan's decisions in insolvency, being the Cape insolvent ordinance, no. 6, 1843, Kaapstad: Juta 1906, p. 410.

54 Debates of the House of Assembly of the Union of South Africa as reported in the Cape Times, 5 May 1916, p. 293.

55 Zie artt. 2 en 87 van Insolvency Act 32 of 1916. Vgl. Cooper v Die Meester en 'n ander 1992 (3) SA 60 (A).

56 Zie: Sacks SALJ 1982, p. 611

57 Supreme Court of Appeal of South Africa Firstrand Bank Ltd v The Land and Agricultural Development Bank of South Africa 2015 (1) SA 38 (SCA). Vgl. Brits 2016, p. 209 e.v.
} 


\section{VAN HOOF}

toekomstige roerende zaken bij voorbaat verpanden. ${ }^{58}$ De invoering van de door Zwalve bepleite regel 'bijzonder gaat voor algemeen' stuit echter op meer bezwaren dan die in het verleden naar voren kwamen (\$3-5). ${ }^{59}$ In de eerste plaats heeft de regel nauwelijks het gewenste effect in situaties waarin de kredietovereenkomst met de eerste schuldeiser de zogenaamde negative pledge-bepaling bevat: de schuldenaar mag geen zekerheid verstrekken aan een andere schuldeiser. Doet hij dat toch, dan pleegt hij wanprestatie. De latere schuldeiser zou door de regel 'bijzonder gaat voor algemeen' een hogere rang krijgen, maar dit is slechts een Pyrrhusoverwinning. De wanprestatie van de schuldenaar geeft de schuldeiser met het oudere zekerheidsrecht de bevoegdheid de leningen op te zeggen en het uitstaande bedrag op te eisen, eventueel gebruik makend van zijn zekerheden. De schuldeiser met het jongere en hogergerangschikte zekerheidsrechten heeft dan weliswaar een hogere rang op een deel van de opbrengst, maar brengt hierdoor de financiële stabiliteit van zijn wederpartij in gevaar. Doorgaans is dit ook niet in het belang van de jongere schuldeiser.

Een ander bezwaar tegen de uitzondering op de prioriteitsregel is dat zij geen rechtvaardiging kent indien de oudere schuldeiser, ondanks zijn generale zekerheidsrechten onderverzekerd is. Dit wil zeggen dat de totale waarde van de verpande zaken lager kan zijn dan de gesecureerde vordering. De ratio achter de regel 'bijzonder gaat voor algemeen' was in het verleden dat de eerste hypotheekhouder een overmaat aan zekerheid had voor zijn gesecureerde vordering en wel wat onderpand kon missen. Als de schuldenaar een andere, latere schuldeiser ten aanzien van een specifiek goed een hoger gerangschikt zekerheidsrecht toekende, hoefde dat de eerdere schuldeiser met allesomvattende zekerheid niet te bijten. Deze had immers voldoende overig onderpand. In het geval de schuldeiser met het oudste zekerheidsrecht ondergedekt is, frustreert de regel 'bijzonder gaat voor algemeen' direct zijn zekerheidspositie.

\section{Art. 3:239 lid $1 \mathrm{BW}$ als tevergeefse rem op allesomvattende zekerheid}

Meer in algemene zin leidt een andere behandeling van of een beperking op allesomvattende zekerheidsrechten zelden tot het gewenste doel, zoals ook blijkt uit de toepassing van artikel 3:239 lid $1 \mathrm{BW}$ in het hedendaagse Nederlandse recht.

58 Art. 3:97 lid 1 BW. Voor 1992 kon een schuldenaar al zijn bestaande en zijn toekomstige roerende zaken bij voorbaat tot zekerheid in eigendom overdragen. HR 22 mei 1953, NJ 1954/189 m.nt. J. Drion (Sio/De Jong); HR 13 maart 1959, NJ 1959/579 m.nt. L.E.H. Rutten (Van Vliet q.q./AB).

59 Deze bezwaren gelden in beginsel niet ten aanzien van een uitzondering op de prioriteitsregel vanwege in rem versio zoals verdedigd door Verheul, 'De wedloop tussen leverancierskrediet en geldkrediet', NTBR 2014/16. Deze uitzondering is namelijk niet gebaseerd op een verschil in de aanduiding van het zekerheidsobject, maar de gedachte dat een leverancier aanspraak kan maken op de verkoopopbrengst van een zaak die zonder hem nooit tot stand was gebracht. 


\section{DE VERGEEFSE UITHOLLING VAN ALLESOMVATTENDE ZEKERHEIDSRECHTEN}

Op grond van dit artikel kan een toekomstige vordering slechts bij voorbaat worden verpand indien zij rechtstreeks zal worden verkregen uit een reeds bestaande rechtsverhouding. Toekomstige vorderingen uit toekomstige rechtsverhoudingen zijn dus niet bij voorbaat te verpanden. De beperking van artikel 3:239 lid $1 \mathrm{BW}$ is een administratieve rem op allesomvattende zekerheid op vorderingen. De Minister van Justititie gaf bij de totstandkoming van de bepaling aan dat de onbeperkte mogelijkheid toekomstige vorderingen te verpanden ten koste zou kunnen gaan van concurrente schuldeisers die derdenbeslag zouden willen leggen. ${ }^{60}$ Aangezien deze schuldeisers ook geen beslag konden leggen op toekomstige vorderingen uit toekomstige rechtsverhoudingen, vond de Minister het gewenst om ook geen pandrecht bij voorbaat op deze vorderingen toe te staan.

Als een schuldeiser toekomstige vorderingen uit toekomstige rechtsverhoudingen als onderpand wil krijgen, is het noodzakelijk om dagelijks pandakten op te maken en te registreren. In de aanloop tot de invoering van het BW wilden de Nederlandse Vereniging van Banken en een aantal banken de verwachte administratieve druk als gevolg van het opstellen en registreren van de pandaktes voorkomen. Hiervoor traden zij in overleg met de registrerende instantie, de Belastingdienst. ${ }^{61}$ Naar aanleiding van dit overleg hebben zij een methode voorgesteld die de administratieve lasten voor de banken en de Belastingdienst moest verminderen. Deze methode behelsde het volgende. Eerst kwamen de bank en de schuldenaar in een zogenaamde stampandakte overeen dat de schuldenaar verplicht was om periodiek zogenaamde borderellen (lijsten) op te stellen. Deze borderellen vermeldden niet alle te verpanden vorderingen afzonderlijk, maar verwezen slechts naar computerlijsten. De computerlijsten specificeerden de afzonderlijke vorderingen door vermelding van de naam van de schuldenaar, een factuurnummer, een factuurdatum en een factuurbedrag. Het geregistreerde borderel bevatte slechts een afzonderlijke aanduiding van de eerste en de laatste vordering van de bijbehorende computerlijst, het totaalsaldo van de op de computerlijst vermelde vorderingen, de datum waarop de computerlijst was opgemaakt en het aantal bladen waaruit de computerlijst bestond. De computerlijsten zelf werden niet geregistreerd. In de stampandakte stond verder dat de bank gevolmachtigd was om de borderellen zelf op te stellen en/of de borderellen ter registratie aan te bieden. Deze wijze van vestiging (bij voorbaat) werd het NVB-model genoemd.

In het arrest Spaarbank Rivierenland/Gispen q.q. sanctioneerde de Hoge Raad dit model. Het college oordeelde dat bepaaldheid niet meebrengt dat 'de vordering in de akte zelf moet worden gespecificeerd door vermelding van bijzonderheden zoals de naam van de debiteur, het nummer van de factuur of een aan de debiteur toegekend cliëntnummer. Voldoende is dat de akte zodanige gegevens bevat dat, eventueel achteraf, aan de hand daarvan kan worden vastgesteld om welke vordering het gaat. ${ }^{162}$

60 Parl. Gesch. Boek 3 (Inv. 3,5 en 6), p. 1337.

61 Hieronder ressorteert de Inspectie der Registratie en Successie.

62 HR 14 oktober 1994, NJ 1995, 447 (Spaarbank Rivierenland/Gispen q.q.). 


\section{VAN HOOF}

De rechtspraktijk bleef aanvankelijk (eventueel naast een generale omschrijving van het pandobject in de pandakte) gebruik maken van computerlijsten. De dagelijkse registratie van deze lijsten leidde feitelijk tot zekerheid met een generaal karakter. In het arrest Mulder q.q./Rabobank oordeelde de Hoge Raad over de bepaaldheid van een pandakte met een algemene omschrijving van de verpande vorderingen zonder verwijzing naar computerlijsten. ${ }^{63}$ De Hoge Raad overwoog dat het bepaaldheidsvereiste van artikel 3:84 lid 2 BW niet in de weg stond aan een generale aanduiding in de pandakte. Na het arrest Mulder q.q./ Rabobank zijn banken gebruik gaan maken van zogenaamde verzamelpandaktes. ${ }^{64}$ In een verzamelpandakte verklaart de bank dat zij alle vorderingen van haar schuldenaren - die haar daartoe een volmacht hebben gegeven - aan zichzelf verpandt. De bank laat de verzamelpandakte dagelijks registreren. De schuldenaren van de bank hebben zich er in het verleden toe verplicht om alle bestaande en toekomstige vorderingen aan de bank te verpanden voor al hetgeen de bank van hen te vorderen zou hebben. Doordat zij de bank een onherroepelijke volmacht hebben gegeven, kan de bank al deze vorderingen van de schuldenaar aan zichzelf verpanden. De Hoge Raad heeft in het arrest Dix q.q./ING geoordeeld dat de verzamelpandakteconstructie tot geldige verpanding leidt. ${ }^{65}$ De beperking van artikel 3:239 lid $1 \mathrm{BW}$ ten spijt, is allesomvattende zekerheid op vorderingen een feit.

Veelal zal een andere behandeling van allesomvattende zekerheid leiden tot een vlucht naar speciale zekerheid ( $\$ 5$ en 6 ). Als er geen werkelijke belemmering bestaat, zal een schuldenaar allerlei goederen specifiek verpanden en daardoor feitelijk allesomvattende zekerheid verschaffen.

\section{De aparte behandeling van allesomvattende zekerheid in het hedendaagse Zuid-} Afrikaanse recht

Zijn er gevallen bekend waarin een andere behandeling van allesomvattende zekerheid niet tot een vlucht naar speciale zekerheid leidt? In de inleiding $(\$ 1)$ wees ik reeds op het hedendaagse Belgische en Zuid-Afrikaanse recht. In deze paragraaf onderzoek ik of het Zuid-Afrikaanse onderscheid tot een vlucht naar speciale zekerheid leidt. De vergelijking met het Zuid-Afrikaanse recht is om verschillende redenen relevant. In de eerste plaats is het Zuid-Afrikaanse recht vanwege de gemeenschappelijke wortels verwant aan het Nederlandse recht. Bovendien kende het Zuid-Afrikaanse recht evenals het Nederlandse recht in het verleden een onderscheid tussen generale en speciale zekerheidsrechten (§6).

63 HR 20 september 2002, NJ 2004, 182 (Mulder q.q./Rabobank).

64 H.J. Damkot \& A.J. Verdaas, 'Verpanding van toekomstige vorderingen beperkt mogelijk; verruiming gewenst?', TvI 9 (2003) 1, p. 7-8.

65

HR 3 februari 2012, NJ 2012, 216 (Dix q.q./ING), r.o. 4.6.3. 


\section{DE VERGEEFSE UITHOLLING VAN ALLESOMVATTENDE ZEKERHEIDSRECHTEN}

Het in 1993 geïntroduceerde nieuwe onderscheid is inmiddels 25 jaar beproefd waardoor zijn functionaliteit te beoordelen is. Ik zet eerst uiteen wat het onderscheid inhoudt en waarom de Zuid-Afrikaanse wetgever het heeft ingevoerd. Daarna ga ik in op de kwestie van de vlucht naar speciale zekerheid $(\S 10)$.

In 1993 introduceerde de Zuid-Afrikaanse wetgever het registerpandrecht op roerende zaken door de invoering van de Wet op Sekerheidstelling deur middel van Roerende Goed. Deze wet maakt een onderscheid tussen notariële pandaktes die een specifieke aanduiding van het onderpand bevatten (special notarial bonds) en notariële pandaktes die een algemene aanduiding van het onderpand bevatten (general notarial bonds). ${ }^{66}$ Artikel 1 van de wet stelt een speciaal registerpandrecht gelijk met een vuistpandrecht op een roerende zaak. Hierdoor heeft de schuldeiser het recht van parate executie indien de schuldenaar in verzuim komt. De schuldeiser mag zijn vorderingen met voorrang boven andere schuldeisers verhalen op de executieopbrengst. Het speciale registerpandrecht is niet alleen tegenwerpbaar aan schuldeisers met jongere registerpandrechten, maar ook aan derde-verkrijgers van de verpande zaken (zaaksgevolg). Het allesomvattende pandrecht, de general notarial bond, heeft geen zakelijke werking. De schuldeiser krijgt 'slechts' het recht om zijn vuistloze zekerheid om te zetten in een vuistpandrecht indien de schuldenaar in verzuim komt. ${ }^{67}$ Deze handeling heet perfection. Indien de schuldeiser deze omzetting niet voltooit voor de faillietverklaring van de schuldenaar, heeft hij slechts voorrang boven concurrente schuldeisers in faillissement. ${ }^{68}$

De voorkeursbehandeling van speciale zekerheid is geïnspireerd door het recht van Natal dat een speciaal verband kende met zakelijke werking jegens derde-verkrijgers, vuistpandhouders en beslagleggers. ${ }^{69}$ Het Natalse speciale verband kwam tot stand door de inschrijving van een notariële akte in een register. Generale verbanden gaven geen voorrang in Natal. ${ }^{70}$ De zakelijke werking werd niet uitgebreid tot generale verbanden, omdat derden moesten kunnen vaststellen welke goederen waren verpand door het register te raadplegen. ${ }^{71}$

$66 \quad$ Vgl. Brits 2016, p. 199.

67 Zie: Brits 2016, p. 212 e.v.

68 Art. 102 Insolvensiewet; Firstrand Bank Ltd v The Land and Agricultural Development Bank of South Africa 2015 (1) SA 38 (SCA). Vgl. Brits 2016, p. 207. Een schuldeiser met een generaal notarieel verband wordt niet tot de 'secured creditors' gerekend. Zie definitie 'security' in art. 2 Insolvensiewet.

69 De rechter in de zaak Turner Bros. v Colville \& Green (1883) 4 NLR 6 geeft een uiteenzetting over de ontwikkelingsgeschiedenis van het speciale verband in Natal. De andere behandeling van speciale vuistloze zekerheid op roerende zaken wijkt af van het Rooms-Hollandse recht, zoals dat in het gewest Holland ten tijde van de Republiek der Zeven Verenigde Nederlanden gold. Tussen schuldeisers met vuistloze pandrechten op roerende zaken gold in het Rooms-Hollandse recht de prioriteitsregel, ongeacht of de pandakte een specifieke of algemene aanduiding van het pandobject bevatte. In het Rooms-Hollandse recht kende een speciaal vuistloos pandrecht geen voordelen boven een generaal vuistloos pandrecht. Vgl. Van Hoof 2015, §4.6.2.

70 Art. 122 van de Natalse Insolventiewet, in: Buchanan's decisions in insolvency, being the Cape insolvent ordinance, no. 6, 1843, Kaapstad: Juta 1906, p. 410.

71 Vgl. Rosenbach \& Co (PTY) Ltd v Dalmonte [1964] 2 All SA 370 (N). 


\section{VAN HOOF}

Het recht van Natal ging met andere woorden uit van de beginselen van publiciteit en specialiteit. De aanduidingen 'winkelinventaris' en 'voorraden' waren niet specifiek genoeg en voldeden niet aan het vereiste van een specifieke aanduiding.

De Zuid-Afrikaanse wetgevingscommissie die zich met de herziening van zakelijke zekerheidsrechten bezig hield in de jaren ' 80 van de vorige eeuw, stelde vast dat het Natalse speciale verband meer tegemoet kwam aan de behoefte van schuldeisers dan het generale verband in de rest van Zuid-Afrika. Vóór 1993 kwam vuistloze zekerheid alleen tot stand door de general notarial bond. Echte zekerheid bood dit niet, aangezien de schuldeiser dit recht niet kon tegenwerpen aan een latere verkrijger of vuistpandhouder. In Natal werden in de jaren '80 meer speciale verbanden gevestigd dan er generale verbanden werden gevestigd in elk van de andere provincies. ${ }^{72}$ Mede om die reden stelde de Zuid-Afrikaanse wetgevingscommissie voor om de Natalse regeling van het speciale verband uit te breiden naar de rest van Zuid-Afrika. ${ }^{73}$ Dit voorstel is uiteindelijk overgenomen in de Wet op Sekerheidstelling deur middel van Roerende Goed van 1993. Anders dan in Natal, geven generale verbanden wel voorrang in het faillissement van de schuldenaar.

De voorkeursbehandeling van speciale zekerheid is gericht op de versterking van de positie van een schuldeiser met behoefte aan vuistloze goederenrechtelijke zekerheid. ${ }^{74}$ De schuldeiser krijgt immers een zekerheidsrecht mét zaaksgevolg (in tegenstelling tot een schuldeiser met een general notarial bond) ${ }^{75}$ De Zuid-Afrikaanse wetgever vindt deze derdenwerking slechts gerechtvaardigd indien derden kennis kunnen nemen van het pandrecht door inzage van het pandregister. ${ }^{76}$

\section{Specialiteit als rem op allesomvattende zekerheid in Zuid-Afrika}

Het vereiste van een specifieke aanduiding vormt vooralsnog een werkelijke belemmering voor een schuldenaar om een veelheid aan goederen specifiek te verpanden en daardoor feitelijk allesomvattende zekerheid te verschaffen. In de uitspraak Ikea Trading and Design $A G$ v. BOE Bank Ltd. vergeleek het hof de specifieke aanduiding van het pandobject met het vereiste van machtsverschaffing bij een vuistpandrecht. ${ }^{77}$ Derden moeten eenvoudig

72 Sekerheidstelling deur middel van roerende goed, Werkstuk 23 Projek 46, p. 56

73 Sekerheidstelling deur middel van roerende goed, Werkstuk 23 Projek 46, p. 121. Zie voor een uitgebreide weergave van de totstandkomingsgeschiedenis: Brits 2016, p. 231 e.v.

74 Sekerheidstelling deur middel van roerende goed, Werkstuk 23 Projek 46, p. 56. Vgl. Brits 2016, p. 238.

75 Vgl. Bokomo v Standard Bank van Suid-Afrika Beperk [1996] 3 All SA 569 (C).

76 Zie over het publiciteitsbeginsel in algemene zin: D.J.Y. Hamwijk, Publicity in secured transactions law (diss. UvA), Rotterdam: Optima 2014, p. 10 e.v.

77 Ikea Trading and Design AG v. BOE Bank Ltd. 2005(2) SA 7 (SCA). 


\title{
DE VERGEEFSE UITHOLLING VAN ALLESOMVATTENDE ZEKERHEIDSRECHTEN
}

kunnen vaststellen welke zaken wel en welke zaken niet zijn verpand. De Supreme Court of Appeal of South Africa overwoog:

\begin{abstract}
"Thus for property to be deemed to be pledged, under section 1(1) of the Act, the bond in question must, without reference to the owner or anyone else, make readily identifiable the property so pledged. Any person seeking to establish, from information in a deeds office, whether a debtor's property is encumbered, must be able to do so from the bond itself. (...) The property must be so described that only it, and not other property of like kind, can be identified as that which is pledged. In my view, there should be no difficulty in identifying machinery, vehicles, even furniture, that is bonded by reference to labels, numbers or bar codes. (...) each of the assets enumerated could be given an identifying mark referred to in the bond. The third party would then readily be able to recognise the thing from the reference in the bond. What is essential is that each item pledged must be recognisable from its description in the bond. ${ }^{78}$
\end{abstract}

De pandakte moet identificatie van de verpande roerende zaken mogelijk maken. Om toch zoveel mogelijk zaken onder het verband te laten vallen, zouden partijen steeds lijsten kunnen registreren waarin zij alle verpande roerende zaken specifiek (met een nummer of iets dergelijks) aanduiden, zoals de Nederlandse banken tot het arrest Spaarbank Rivierenland/Gispen q.q. vorderingen specifiek in de akte aanduidden. ${ }^{79}$ Hiervoor is wel vereist dat de verpande zaken zich voor dergelijke identificatie lenen. Veel vervangbare en niet individualiseerbare zaken vallen daarom al af. Periodieke aktes met allesomvattende opsommingen lijken niet in gebruik te zijn in Zuid-Afrika. Sterker nog, uit de literatuur blijkt dat de praktijk nauwelijks gebruik maakt van het speciale notariële verband ${ }^{80}$ Sonnekus wijst op het nadeel dat partijen een speciaal verband niet bij voorbaat kunnen vestigen op toekomstige zaken. ${ }^{81}$ Dit vormt met name een belemmering voor schuldenaren met een steeds wisselende voorraad van waardevolle (en identificeerbare) roerende zaken zoals auto's. Brits wijt de impopulariteit aan het feit dat 'the legal principles surrounding the Act - its requirements and consequences - are still largely underdeveloped, undertheorised and/or misunderstood. ${ }^{182}$ Brits geeft bovendien aan dat het systeem van registratie mogelijk te duur en

78 Ikea Trading and Design AG v. BOE Bank Ltd. 2005(2) SA 7 (SCA), r.o. 22 en 24.

79 De verwijzing naar buiten de akte gelegen, niet publiekelijk beschikbare stukken, zoals bij het NVBmodel, lijkt haaks te staan op de bedoeling van de Zuid-Afrikaanse wetgever. Vgl. HR 14 oktober 1994, NJ 1995, 447 (Spaarbank Rivierenland/Gispen q.q.).

80 J.C. Sonnekus, 'Omskrywing van Sekerheidsobjekte vir die Doeleindes van die Wet op Sekerheidstelling deur Middel van Roerende Goed 57 van 1993', 38 De Jure 133 (2005), p. 133; R. Brits, 'Two decades of special notarial bonds in terms of the security by means of movable property act', 2015 SA Merc LJ, p. 247.

81 J.C. Sonnekus, 'Omskrywing van Sekerheidsobjekte vir die Doeleindes van die Wet op Sekerheidstelling deur Middel van Roerende Goed 57 van 1993', 38 De Jure 133 (2005), p. 137; J.C. Sonnekus, 'Voertuigvloot as sekerheidsobjek', THRHR (2000) 63, p. 645.

82 R. Brits, 'Two decades of special notarial bonds in terms of the security by means of movable property act', 2015 SA Merc LJ, p. 247. 


\section{VAN HOOF}

tijdrovend is.

Sonnekus leidt uit het Ikea-arrest af dat een pandakte kan verwijzen naar een batenregister of inventaris 'mits maar erken word dat daar die plek is vir ' $n$ verwysing in die verbandakte, na 'n "sleutelkenmerk" van die belaste sake wat in 'n bylaag soos 'n behoorlike bateregister van die verbandgewer benut word om die sekerheidsobjekte sonder twyfel kenbaar te maak'. ${ }^{83}$ Hij verdedigt bovendien de mogelijkheid van het voorzien van een merkteken op de verpande zaken om het pandrecht kenbaar te maken. ${ }^{84}$ De akte vermeldt dan dat de zaken zijn verpand die zijn voorzien van een merkteken, eventueel in een voor derden toegankelijk inventarisregister. ${ }^{85}$ Brits noemt Sonnekus' benadering goed verdedigbaar, maar geeft aan dat het onzeker is hoe een rechter hierover zal oordelen. ${ }^{86}$ Ter bevordering van de rechtszekerheid acht Brits concrete richtlijnen voor identificatie noodzakelijk, eventueel voortvloeiend uit jurisprudentie, maar idealiter uit de wet. Verder adviseert Brits de Zuid-Afrikaanse wetgever om digitalisering van het pandregister te overwegen ${ }^{87}$ Digitalisering kan volgens hem leiden tot een eenvoudiger, goedkoper en sneller systeem van registratie en publiciteit. Ook noemt hij de mogelijkheid om het vereiste van een specifieke aanduiding van het zekerheidsobject minder strikt te maken. ${ }^{88}$

Vooralsnog lijken de vereisten van registratie en specifieke aanduiding in de akte te voorkomen dat een schuldenaar een veelheid aan roerende zaken verpandt en daardoor feitelijk allesomvattende zekerheid verschaft. Indien Sonnekus in de jurisprudentie navolging krijgt, bestaat het risico dat een schuldenaar nagenoeg al zijn zaken van een merkteken voorziet (fysiek of in een digitaal inventarissysteem) als zijn schuldeiser hem daarom vraagt. Speciale zekerheid zal dan een allesomvattend karakter kunnen krijgen. Op vergelijkbare wijze kunnen het door Brits genoemde voorstellen tot digitalisering of versoepelen van het aanduidingsvereiste de belemmering om een veelheid aan zaken te verpanden wegnemen.

\section{Tot slot}

Indien een wetgever allesomvattende zekerheid zwakkere werking toekent dan speciale

J.C. Sonnekus, 'Omskrywing van Sekerheidsobjekte vir die Doeleindes van die Wet op Sekerheidstelling deur Middel van Roerende Goed 57 van 1993', 38 De Jure 133 (2005), p. 135-6. Ibidem, p. 137; J.C. Sonnekus, 'Voertuigvloot as sekerheidsobjek', THRHR (2000) 63, p. 645.

J.C. Sonnekus, 'Omskrywing van Sekerheidsobjekte vir die Doeleindes van die Wet op Sekerheidstelling deur Middel van Roerende Goed 57 van 1993', 38 De Jure 133 (2005), p. 138.

R. Brits, 'Two decades of special notarial bonds in terms of the security by means of movable property act', 2015 SA Merc LJ, p. 267; Brits 2016, p. 249.

Brits 2015, p. 272.

Brits 2016, p. 250. 
zekerheid, kan dit leiden tot een vlucht naar speciale zekerheid. Zonder werkelijke belemmering kan een schuldenaar een veelheid aan goederen specifiek verpanden en daardoor feitelijk allesomvattende zekerheid verschaffen. Deze werking blijkt onder meer uit de toepassing van de regel 'bijzonder gaat voor algemeen' in Nederland en Zuid-Afrika in het verleden (§3-6) én uit de hedendaagse Nederlandse praktijk van de verpanding van vorderingen $(\S 8)$. Het hedendaagse Zuid-Afrikaanse onderscheid tussen generale en speciale zekerheid lijkt niet tot een vlucht naar speciale zekerheid te hebben geleid. Vooralsnog lijken het registratievereiste en het vereiste van een specifieke aanduiding een werkelijke belemmering te zijn voor het specifiek verpanden van nagenoeg alle zaken. De geschiedenis leert echter dat het wegvallen van de belemmeringen ertoe zal leiden dat de schuldenaar al zijn goederen afzonderlijk zal verpanden en de schuldeiser daardoor langs een omweg alsnog allesomvattende zekerheid krijgt. Indien de wetgever gehoor geeft aan de oproep om de sterke positie van banken te verzwakken ten gunste van andere schuldeisers, moet hij voorkomen dat dit leidt tot een vlucht naar speciale zekerheid en het gesuggereerde probleem niet wordt opgelost. De oplossing is niet een pakkende one-liner zoals 'bijzonder gaat voor algemeen', maar ook niet per se 'eerder in tijd sterker in recht'. ${ }^{89}$

89 Beuving \& Tjittes huldigden bijvoorbeeld de opvatting dat een bank op grond van de aanvullende werking van de redelijkheid en billijkheid een teveel aan zekerheid vrij moet geven. Zie: J. Beuving en R.P.J.L. Tjittes, 'Het tegengaan van een overmaat aan zekerheden', NJB 73 (1998) 34, p. 1549. Verder verdedigde Verheul de hogere rang van een leverancier boven de bank (met stille pandrechten op nagenoeg alle vorderingen van de schuldenaar) op de opbrengst van een onder eigendomsvoorbehoud geleverde zaak die de afnemer in zijn normale bedrijfsuitoefening vervreemdt. Zie: E.F. Verheul, 'De wedloop tussen leverancierskrediet en geldkrediet', NTBR 2014/16; Vgl. Van Hoof 2015, §10.4.2.1.

90 Vincent van Hoof is universitair docent Rechtsgeschiedenis aan de Radboud Universiteit en verbonden aan het Onderzoekcentrum Onderneming \& Recht. 
VAN HOOF

GROM (2019)

online publicatie GROM XXXVI (2019) 